\title{
Development of composite radial filter for recharging aquifers with canal water
}

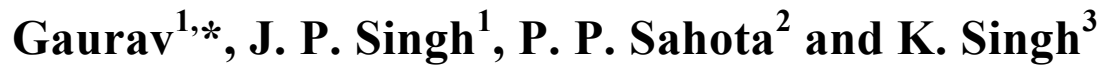 \\ ${ }^{1}$ Department of Soil and Water Engineering, ${ }^{2}$ Department of Microbiology, \\ ${ }^{3}$ Department of Soil Science, Punjab Agricultural University, Ludhiana 141 027, India
}

\begin{abstract}
A laboratory scale model of composite radial filter was designed, fabricated and tested for recharging aquifer with canal water. Charcoal $(C)$, coarse sand (CS) and gravel (G) filter materials were placed in annular rings of developed radial filter in different combination of thickness, viz. $1: 1: 1,1: 1: 2,1: 2: 2$ and $1: 2: 1$ for four treatments $T_{1}, T_{2}, T_{3}$ and $T_{4}$ respectively. Flow equation for discharge through composite radial filter was developed and verified through experiments. The design depth of the filter for given discharge was also obtained. Sodium hypochlorite solution was injected through chlorination unit at the outlet of the radial filter to remove the bacteriological contamination of filtered water. The performance of composite radial filter was evaluated by analyzing canal water before and after filtration. Water quality parameters of filtered water were found to be within permissible limit at low flow rate $(0.3 \mathrm{lps})$. The water quality parameters of filtered water from treatment $T_{3}$ with thickness of 10,20 and $20 \mathrm{~cm}$ for $\mathrm{C}$, $\mathrm{CS}$ and $\mathrm{G}$ respectively was found to be comparatively better than other three treatments $\left(T_{1}, T_{2}\right.$ and $\left.T_{4}\right)$. The composite radial filter consists of $C, C S$ and $G$ filter media having thickness in ratio of $1: 2: 2$ was found to be the best for recharging groundwater aquifer with canal water.
\end{abstract}

Keywords: Aquifer, artificial recharge, canal water, composite radial, filter.

GROUNDWATER is the major source of freshwater that caters to the demand of the ever-growing domestic, agricultural and industrial sectors which have put severe pressure on the available resources and have adversely impacted groundwater levels ${ }^{1}$. The water table is declining at an alarming rate in about $15 \%$ of India's geographical area ${ }^{2}$. Water tables in fresh groundwater regions of the northwestern states of India, particularly, Haryana and Punjab, are falling at an annual rate of 25 $70 \mathrm{~cm}$ over the past $2-3$ decades $^{3}$. In order to improve the sustainability of groundwater resources, it is necessary to recharge the depleted groundwater aquifers through artificial recharge techniques. These techniques must be combined with an efficient filtering unit to prevent physi-

*For correspondence. (e-mail: gauravmaahi895@gmial.com) cal, chemical and biological impurities from entering into the groundwater aquifer. The frequent clogging of filter material due to suspended sediments in the surface water slows down the recharge rate and reduces the efficiency and effectiveness of the filter. An optimum design should be evolved considering other factors such as amount and type of inflow water, soil and climate characteristics, vegetation, population and location. The most critical issues with regard to efficiency of the filtering unit are clogging and water quality. A study on recharge of defunct bore wells through filter bed composed of boulders, jelly stones, charcoal and sand was conducted in Bengaluru, Karnataka, and the quality of recharged water was found within permissible limit for drinking purpose ${ }^{4}$. The physico-chemical characteristics of Ganga canal water at Haridwar and Allahabad regions were determined, and water quality parameters were found within the permissible limit for irrigation ${ }^{5,6}$. However, turbidity was above the limit and water could be used for domestic purposes after suitable treatments. The physico-chemical and biological parameters of Phuleli canal water in Hyderabad were studied and the water quality parameters specially BOD, COD, TDS and MPN were found to be more than the permissible limit, thus unfit for human consumption without suitable treatment ${ }^{7}$. Canal water contains waste flowing through drains and rivers, especially during off-season or ripening crop period. This water could be utilized for recharging groundwater aquifers after purification using suitable filtration unit. The safety of reclaimed water reuse was evaluated in a lab-scale artificial groundwater recharge system using a set of bioassays (acute toxicity to Daphnia, genotoxicity, estrogenic and antiestrogenic toxicity), to remove toxicity from $56 \%$ to $99 \%$ through ozonation ${ }^{8}$. An experiment was conducted for artificial recharge of groundwater with canal water through shallow shafts by placing filter pack materials, viz. $9.5-4.8 \mathrm{~mm}$ pea gravel and $4.8-0.007 \mathrm{~mm}$ concrete sand in Fresno, California, USA and clogging was observed within the filter-pack material ${ }^{9}$. An artificial recharge system was designed with filtration device, including a constructed wetland, settling pond and a porous recharge reservoir. The constructed wetland has aquatic vegetation receives water from a surface water source goes to porous reservoir through settling tank to remove sediments and chemicals from the water. A back 
flush tube was installed within the sand layer in the porous recharge reservoir to remove sediment and particulates from the layer ${ }^{10}$. The various filter materials, viz. cocopeat, brick flakes, gravel, coarse sand, charcoal, corncob, cotton, silica, pebbles, etc. can be used for filtration of water separately or in combination. A portable gravel sand filter and sedimentation tank with fine gravel filter using coagulant was designed; and the recharge rate was observed to decrease within $20 \mathrm{~h}$ and Escherichia coli could not be trapped in $22.5 \mathrm{~cm}$ sand thickness. Alum was used as a coagulant in sedimentation tank which detained $8 \%$ of sediment load while gravel filter detained up to $83.7 \%$ of sediment passing through it $^{11}$. A column study on hydraulic performance of granular filter media and the effect of physical characteristics of filter media and flow-through rates on the clogging of stormwater filters was carried out with five replicate experiments using zeolite, scoria, river sand and polymeric glass beads and different flow-through rates. It was found that all media, except scoria clogged after similar volumes of storm water, but scoria-based filters were found to be highly variable in performance. Zeolite filters with the lowest flow rate had an overall treatment efficiency of $88 \%$ (ref. 12). A sand-based filtration system (column study) for groundwater recharge wells was evaluated and the results indicated that more than $60 \%$ suspended solids were entrapped in the upper layer of coarse sand. The removal efficiency improved with increasing thickness of the sand layer and recharge rate declined for greater sediment concentration $(>100 \mathrm{mg} / \mathrm{l})$. The field studies revealed that $0.7-1.0 \mathrm{~mm}$ particle size and $75 \mathrm{~cm}$ thickness of the sand layer with sediment tanks or biological filters near the recharge structures reduced the sediment load of run-off water ${ }^{3}$. An artificial well recharge system with filtration unit was designed near an open well composed of $30 \mathrm{~cm}$ stones, $30 \mathrm{~cm}$ sand and $30 \mathrm{~cm}$ gravel particles. The filtration efficiency of primary filter was determined and found to be $64-70 \%$; for the main filter it was $90-94 \%$ (ref. 13). Laboratory experiment on filtration system (rectangular column) consisting of coarse sand, gravel and pebbles for groundwater recharge well was conducted, which revealed that $100 \%$ of suspended solids were entrapped in the upper layer of medium sand and that recharge rates declined greater for influent concentration $\left(>100 \mathrm{mg} / \mathrm{l}^{14}\right.$. A laboratory experiment was conducted in a rectangular column to evaluate the performance of a filter system consisting of coarse sand, gravel and pebble layers of variable thickness for recharging storm-water run-off. Medium sand of three particle sizes $(0.150-0.300,0.300-0.425$ and $0.425-$ $0.600 \mathrm{~mm}$ ) of thickness 25,30 and $35 \mathrm{~cm}$ respectively, in the top layer of the filter system with influent sediment concentration of 250-3000 mg/l entrapped $100 \%$ suspended solids in the upper $10 \mathrm{~cm}$ layer and the recharge rates declined sharply for influent concentration of more than $1000 \mathrm{mg} / \mathrm{l}$. All treatments with greater thickness of me- dium sand indicated recharge rate slightly more than those with smaller thickness ${ }^{15}$. The siltation and trash settle down on the floor of the filtration unit of the radial filter instead of the filtering surface in case of vertical filter. The present study was undertaken to develop a laboratoryscale model of composite radial filter for recharging aquifers.

\section{Materials and methods}

The filter materials, viz. brick flakes, gravel, coarse sand and charcoal were selected for the development of composite radial filter based on the literature. The filter materials - charcoal (particle size 2-4 mm), coarse sand (1.18$2 \mathrm{~mm}$ ) and gravel (2-4 mm) were used at different thickness combination ratios, viz. $1: 1: 1,1: 1: 2,1: 2: 2$ and $1: 2: 1$. The composite radial filter consists of a circular galvanized iron (GI) sheet of 8 gauge made of cylindrical shape of height $45 \mathrm{~cm}$ and radius $100 \mathrm{~cm}$ to support the filter materials. Concentric rings of iron mesh of height $45 \mathrm{~cm}$ were fabricated at $10 \mathrm{~cm}$ interval on the base of the GI sheet and wrapped with nylon net. These rings were made for various treatments starting from the outer periphery of the GI sheet. Small iron rods provide support to these rings in which the selected filter materials of different thickness were placed. The brick flakes were placed in the outer concentric ring $\left(r_{o}=100 \mathrm{~cm}\right.$ and $\left.r_{i}=90 \mathrm{~cm}\right)$ to prevent trash, litter, foreign materials, sediments, etc. from entering the canal water. Chlorination unit was fitted at the centre (outlet) of the filter. Four treatments for different thicknesses of filter medium in composite radial filter were used (Table 1).

Canal water was allowed to flow through the filter and filtered water exited from the centre of the inner concentric ring. Figure 1 shows the schematic diagram of composite radial filter with filter materials. According to a study, about $0.1 \mathrm{ml}$ volume of $5 \%$ sodium hypochlorite solution per litre of water is required for chlorination $(\mathrm{N}$. Singh, unpublished). The calibrated value of sodium hypochlorite for 1.3 and $0.3 \mathrm{lps}$ discharge was found to be 0.13 and $0.03 \mathrm{ml} / \mathrm{s}$ respectively. The sodium hypochlorite solution was injected at the calibrated discharge rate into filtered water through chlorination unit consists of plastic can attached with the cannula opening at the outlet.

Canal water samples were collected aseptically in a pre-sterilized glass bottles (1 litre) for analysis of MPN index, total coliforms, faecal coliforms $-E$. coli standard methods (IS-10500-1991 BIS, New Delhi). Physicochemical analysis of water samples, viz. pH, TDS, BOD, COD and TSS was performed.

\section{Results and discussion}

A laboratory-scale model of composite radial filter having gravel, coarse sand and charcoal filter materials 
Table 1. Different combinations of filter medium

\begin{tabular}{lcccc}
\hline Treatment & $\begin{array}{c}\text { Thickness of charcoal } \\
\left(d_{\mathrm{c}} ; \mathrm{cm}\right)\end{array}$ & $\begin{array}{c}\text { Thickness of coarse sand } \\
\left(d_{\mathrm{cs}} ; \mathrm{cm}\right)\end{array}$ & $\begin{array}{c}\text { Thickness of gravel } \\
\left(d_{\mathrm{g}} ; \mathrm{cm}\right)\end{array}$ & $\begin{array}{c}\text { Total thickness } \\
(D ; \mathrm{cm})\end{array}$ \\
\hline$T_{1}$ & 10 & 10 & 10 & 30 \\
$T_{2}$ & 10 & 10 & 20 & 40 \\
$T_{3}$ & 10 & 20 & 20 & 50 \\
$T_{4}$ & 10 & 20 & 10 & 40 \\
\hline
\end{tabular}

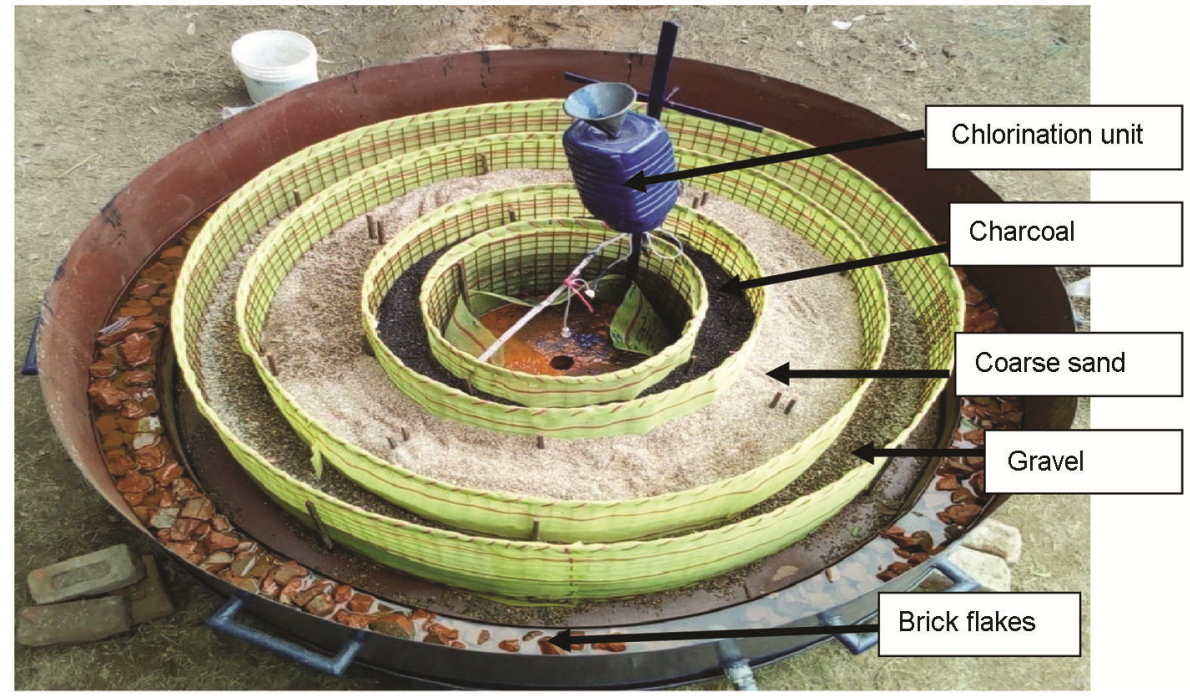

Figure 1. View of composite radial filter with filter medium and chlorination unit.

was designed for recharging aquifers with canal water. The hydraulic conductivity of these materials were experimentally determined to be $2.44,0.88$ and $2.14 \mathrm{~cm} / \mathrm{s}$ respectively.

\section{Determination of hydraulic conductivity of composite radial filter}

The equivalent hydraulic conductivity of composite radial filter was obtained mathematically using Darcy's law

$$
K_{\mathrm{e}}=D /\left(d_{1} / K_{1} r_{1}+d_{2} / K_{2} r_{2}+d_{3} / K_{3} r_{3}\right) r_{0},
$$

where $D$ is the total thickness of the filter materials $(\mathrm{cm})$, $d_{1}$ the thickness of charcoal filter material $(\mathrm{cm}), d_{2}$ the thickness of coarse sand $(\mathrm{cm}), d_{3}$ the thickness of gravel filter material $(\mathrm{cm}), K_{\mathrm{e}}$ the equivalent hydraulic conductivity of composite filter $(\mathrm{cm} / \mathrm{s}), K_{1}$ the hydraulic conductivity of charcoal $(\mathrm{cm} / \mathrm{s}), K_{2}$ the hydraulic conductivity of coarse sand $(\mathrm{cm} / \mathrm{s}), K_{3}$ the hydraulic conductivity of gravel $(\mathrm{cm} / \mathrm{s}), r_{0}$ the inner radius of charcoal concentric ring $(\mathrm{cm}), r_{1}$ the outer radius of charcoal concentric ring $(\mathrm{cm}), r_{2}$ the outer radius of coarse sand concentric ring $(\mathrm{cm})$ and $r_{3}$ is the outer radius of gravel concentric $\operatorname{ring}(\mathrm{cm})$.
The flow equation of water at the outlet of the filter is governed by Darcy's law

$$
Q=\left[2 \pi r_{\mathrm{o}} K_{\mathrm{c}} h_{w}{ }^{2}\right] / D,
$$

where $D$ is the thickness of the composite filter materials (radial distance from outer to inner layer; $\mathrm{cm}$ ). $K_{\mathrm{c}}$ the hydraulic conductivity of composite radial filter $(\mathrm{cm} / \mathrm{s})$, $h_{\mathrm{w}}$ the head at the outer layer of the composite radial filter $(\mathrm{cm}), Q$ the discharge from composite radial filter $\left(\mathrm{cm}^{3} / \mathrm{s}\right)$ and $r_{\mathrm{o}}$ is the radius of the inner layer of composite radial filter $(\mathrm{cm})$.

The equivalent hydraulic conductivity of composite radial filter was determined by measuring the hydraulic conductivity of filter materials separately. The conductivity for four combination treatments was computed using eq. (1) and the average equivalent hydraulic conductivity $\left(K_{\mathrm{e}}\right)$ was found to be $2.36 \mathrm{~cm} / \mathrm{s}$ (Table 2$)$.

An experiment was conducted with various discharges and thicknesses of filter materials placed in the composite radial filter. The hydraulic conductivity of the composite filter was determined experimentally for each treatment using eq. (2) based on Darcy's law and design depth of filter material was also computed considering $0.5 \mathrm{~cm}$ free board for taking care of capillary rise (Table 3). The average hydraulic conductivity of the composite filter $\left(K_{\mathrm{c}}\right)$ 
Table 2. Equivalent hydraulic conductivity of composite filter materials

\begin{tabular}{|c|c|c|c|c|c|c|c|c|}
\hline \multirow[b]{2}{*}{ Treatment } & \multicolumn{3}{|c|}{ Radius $(\mathrm{cm}) r_{\mathrm{o}}=40 \mathrm{~cm}$} & \multicolumn{4}{|c|}{ Thickness (cm) } & \multirow{2}{*}{$\begin{array}{l}\text { Equivalent hydraulic } \\
\text { conductivity }\left(K_{\mathrm{e}} ; \mathrm{cm} / \mathrm{s}\right)\end{array}$} \\
\hline & $r_{1}$ & $r_{2}$ & $r_{3}$ & $d_{1}$ & $d_{2}$ & $d_{3}$ & $D$ & \\
\hline$T_{1}$ & 50 & 60 & 70 & 10 & 10 & 10 & 30 & 2.23 \\
\hline$T_{2}$ & 50 & 60 & 80 & 10 & 10 & 20 & 40 & 2.59 \\
\hline$T_{3}$ & 50 & 70 & 90 & 10 & 20 & 20 & 50 & 2.47 \\
\hline \multirow[t]{2}{*}{$T_{4}$} & 50 & 70 & 80 & 10 & 20 & 10 & 40 & 2.16 \\
\hline & & & & & & & & Average $=2.36$ \\
\hline
\end{tabular}

Table 3. Hydraulic conductivity of composite filter materials

\begin{tabular}{lrccrc}
\hline $\begin{array}{l}\text { Discharge } \\
\left(\mathrm{cm}^{3} / \mathrm{s}\right)\end{array}$ & $\begin{array}{r}\text { Head } \\
(\mathrm{cm})\end{array}$ & $\begin{array}{c}\text { Thickness } \\
(\mathrm{cm})\end{array}$ & $\begin{array}{c}\text { Hydraulic } \\
\text { gradient }\end{array}$ & $\begin{array}{c}\text { Design depth } \\
(\mathrm{cm})\end{array}$ & $\begin{array}{c}\text { Hydraulic conductivity } \\
\left(K_{\mathrm{c}}, \mathrm{cm} / \mathrm{s}\right)\end{array}$ \\
\hline 1419.33 & 11.9 & 30 & 0.40 & 12.4 & 1.18 \\
788.67 & 7.9 & 30 & 0.26 & 8.4 & 1.53 \\
266.00 & 3.8 & 30 & 0.13 & 4.3 & 2.14 \\
80.00 & 2.1 & 30 & 0.07 & 2.6 & 2.17 \\
1380.00 & 11.1 & 40 & 0.28 & 11.6 & 1.77 \\
826.00 & 8.0 & 40 & 0.20 & 8.5 & 3.06 \\
354.00 & 4.0 & 40 & 0.10 & 4.5 & 3.15 \\
83.33 & 2.1 & 40 & 0.05 & 2.6 & 1.43 \\
1338.00 & 13.7 & 50 & 0.27 & 14.2 & 3.36 \\
841.33 & 7.1 & 50 & 0.14 & 7.6 & 3.70 \\
318.00 & 4.2 & 50 & 0.08 & 4.7 & 4.20 \\
77.33 & 1.8 & 50 & 0.04 & 2.3 & 1.20 \\
1239.33 & 12.8 & 40 & 0.32 & 13.3 & 1.75 \\
786.00 & 8.5 & 40 & 0.21 & 9.0 & 2.41 \\
300.67 & 4.5 & 40 & 0.11 & 5.0 & 3.16 \\
79.33 & 2.0 & 40 & 0.05 & 2.5 & Average $=2.42$ \\
\hline
\end{tabular}

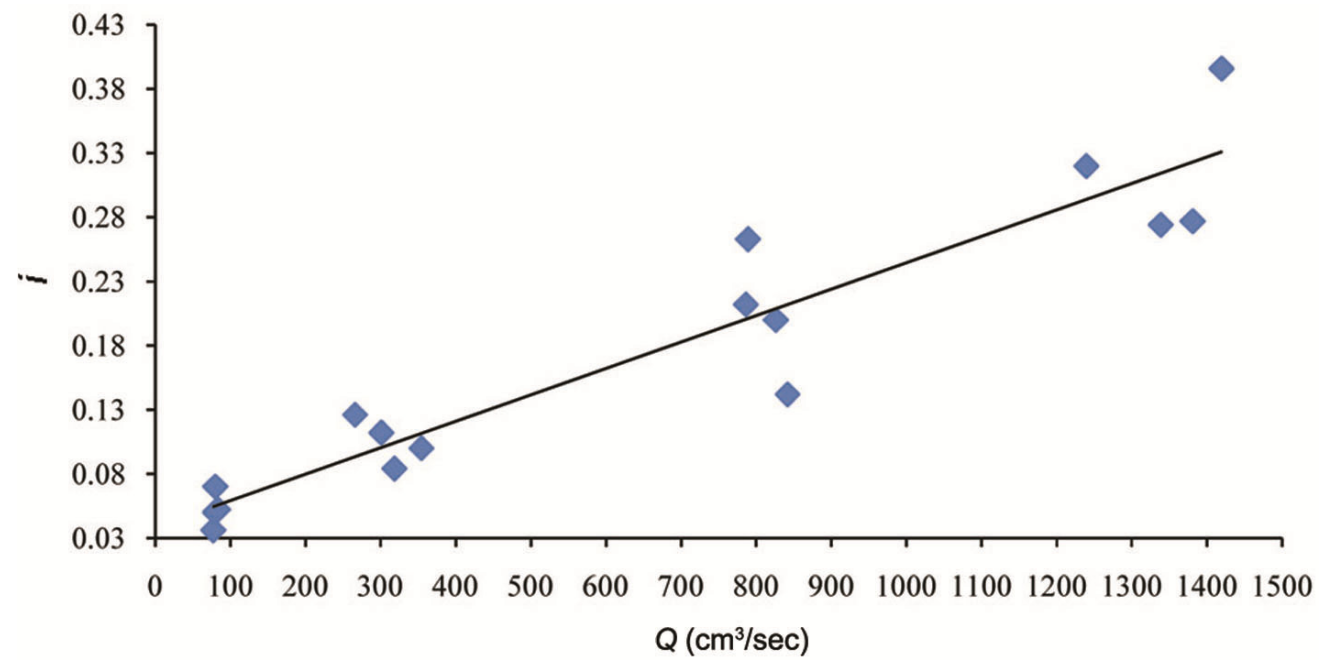

Figure 2. Relationship between discharge $(Q)$ and hydraulic gradient $(i)$.

was found to be $2.42 \mathrm{~cm} / \mathrm{sec}$. Tables 2 and 3 show the values of $K_{\mathrm{e}}$ and $K_{\mathrm{c}}$ to be 2.36 and $2.42 \mathrm{~cm} / \mathrm{sec}$ respectively, which are closed to each other. A straight-line relationship was obtained between discharge from composite radial filter and hydraulic gradient at the inlet and outlet (Figure 2), which indicates that the flow through composite radial filter follows Darcy's law. A straight-line relationship was also found between discharge through composite radial filter and depth of the filter materials as shown in Figure 3, and the equation for designing depth of filter was obtained from the figure and expressed as $h_{\mathrm{d}}=0.007 \mathrm{Q}+1.8$. 


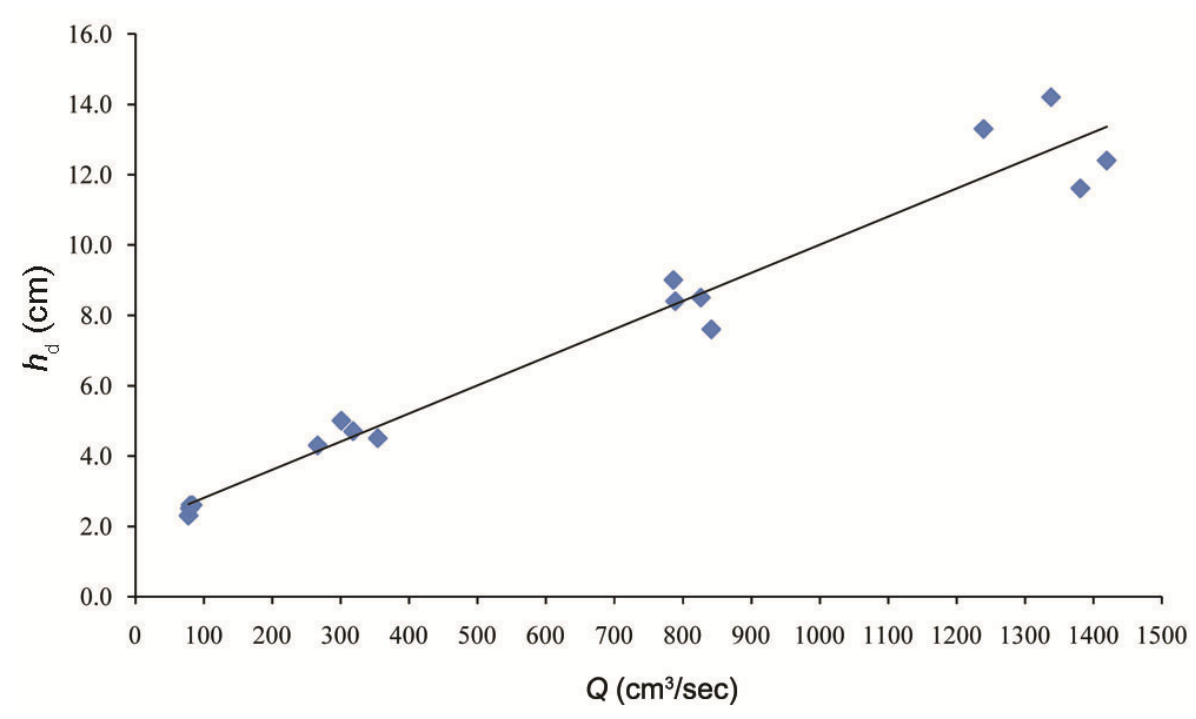

Figure 3. Relationship between discharge $(Q)$ and design depth $\left(h_{\mathrm{d}}\right)$.

Table 4. Water quality parameters before and after filtration

\begin{tabular}{|c|c|c|c|c|c|c|c|c|c|c|c|c|c|}
\hline \multirow[b]{3}{*}{ Parameters } & \multirow{2}{*}{\multicolumn{4}{|c|}{ Before filtration }} & \multicolumn{8}{|c|}{ After filtration } & \multirow[b]{3}{*}{ Permissible limit } \\
\hline & & & & & \multicolumn{4}{|c|}{$Q_{1}=1.3 \mathrm{l} / \mathrm{s}$} & \multicolumn{4}{|c|}{$Q_{2}=0.3 \mathrm{l} / \mathrm{s}$} & \\
\hline & $T_{1}$ & $T_{2}$ & $T_{3}$ & $T_{4}$ & $T_{1}$ & $T_{2}$ & $T_{3}$ & $T_{4}$ & $T_{1}$ & $T_{2}$ & $T_{3}$ & $T_{4}$ & \\
\hline MPN & 1100 & 1100 & 1100 & 1100 & 7 & 7 & 7 & 7 & 3 & 3 & 3 & 3 & $<3 / 100 \mathrm{ml}$ \\
\hline pH & 8.1 & 8.1 & 8.2 & 8 & 8.3 & 8.5 & 8.4 & 8.5 & 8.1 & 8.4 & 8.5 & 8.5 & $6.5-8.5$ \\
\hline TDS (ppm) & 117 & 120 & 128 & 115 & 132 & 145 & 132 & 156 & 117 & 112 & 106 & 129 & 500 \\
\hline BOD (ppm) & 192 & 198 & 180 & 182 & 56 & 36 & 12 & 32 & 44 & 28 & 4 & 20 & 3 \\
\hline COD (ppm) & 352 & 320 & 334 & 344 & 112 & 80 & 32 & 64 & 96 & 64 & 16 & 48 & 7 \\
\hline
\end{tabular}

Table 5. Analysis of total suspended solids (TSS)

\begin{tabular}{lccccc}
\hline & \multicolumn{3}{c}{ Treatment } \\
\cline { 2 - 3 } & \multicolumn{2}{c}{ TSS $(1500 \mathrm{ppm})$} & & \multicolumn{2}{c}{ TSS (2000 ppm) } \\
\cline { 2 - 3 } \cline { 5 - 6 } TSS concentration & TSS (ppm) after filtration & $\%$ TSS retained & & TSS (ppm) after filtration & $\%$ TSS retained \\
\hline$T_{1}$ & 760 & 50.67 & & 1024 & 51.20 \\
$T_{2}$ & 560 & 37.33 & & 687 & 34.33 \\
$T_{3}$ & 280 & 18.67 & & 384 & 19.21 \\
$T_{4}$ & 400 & 26.67 & & 551 & 27.53 \\
\hline
\end{tabular}

\section{Performance of the developed composite radial filter}

The performance of the composite radial filter was evaluated by analysing bacteriological, physico-chemical and biological water quality parameters of canal water before and after filtration for the four treatments. The canal water quality parameters were tested before and after filtration for all treatments; and less variation was found (Table 5). MPN analysis was performed for the presence of coliforms in canal water samples before filtration and found to be $1100 / 100 \mathrm{ml}$, which is much higher than the permissible limit $(<3 \mathrm{MPN} / 100 \mathrm{ml})$ for drinking purposes. The values of BOD and COD of canal water before filtration were found to be above permissible limits. The bacteriological, physico-chemical and biological analysis of canal water samples before filtration indicated that canal water is not suitable for recharging groundwater aquifers.

The same canal water was allowed to flow through the developed composite radial filter under four treatments at two different discharges $\left(Q_{1}\right) \quad 1.3$ and $\left(Q_{2}\right) \quad 0.3$ lps. Sodium hypochlorite solution at a rate of 0.13 and $0.03 \mathrm{ml} / \mathrm{sec}$ for flow rate of 1.3 and $0.3 \mathrm{lps}$ respectively, was injected at the outlet of the filtered water through chlorination unit. The water quality parameters of the 


\section{RESEARCH ARTICLES}

filtered water, for all the four treatments at the two flow rates were tested (Table 4). The values of MPN, COD and BOD of filtered water from all the treatments were found to be low and close to permissible limits, except $\mathrm{pH}$ and TDS which were higher but within permissible limits (Table 4). The values of MPN, COD, BOD and TDS of filtered water at discharge $Q_{2}$ were found to be lower than the values at discharge $Q_{1}$, except $\mathrm{pH}$. However, MPN value was found to be $7 / 100 \mathrm{ml}$ and $3 / 100 \mathrm{ml}$ at flow rate $Q_{1}$ and $Q_{2}$ respectively, for all the treatments (Figure 4), which is within the permissible limit. Higher doses of sodium hypochlorite solution are required for reducing MPN value of filtered water for higher flow rate ( $>0.3 \mathrm{lps}$ ). However, the values of $\mathrm{pH}$ and TDS had slightly increased due to charcoal residue and sodium hypochlorite solution, and were found to be within permissible limits.

The values of MPN, TDS, BOD and COD were less at low flow rate because of more residual time to filter contaminants (Figures 4-6). The experiment showed that lower the flow rate through the composite radial filter, better quality of filtered water. The water quality parameters for treatment $T_{3}$ were found to be lowest compared to the other three treatments for both flow rates (Table 4 and Figures 4-6). The filter medium with treatment $T_{3}$ was found to be the best combination for filtration of canal water.
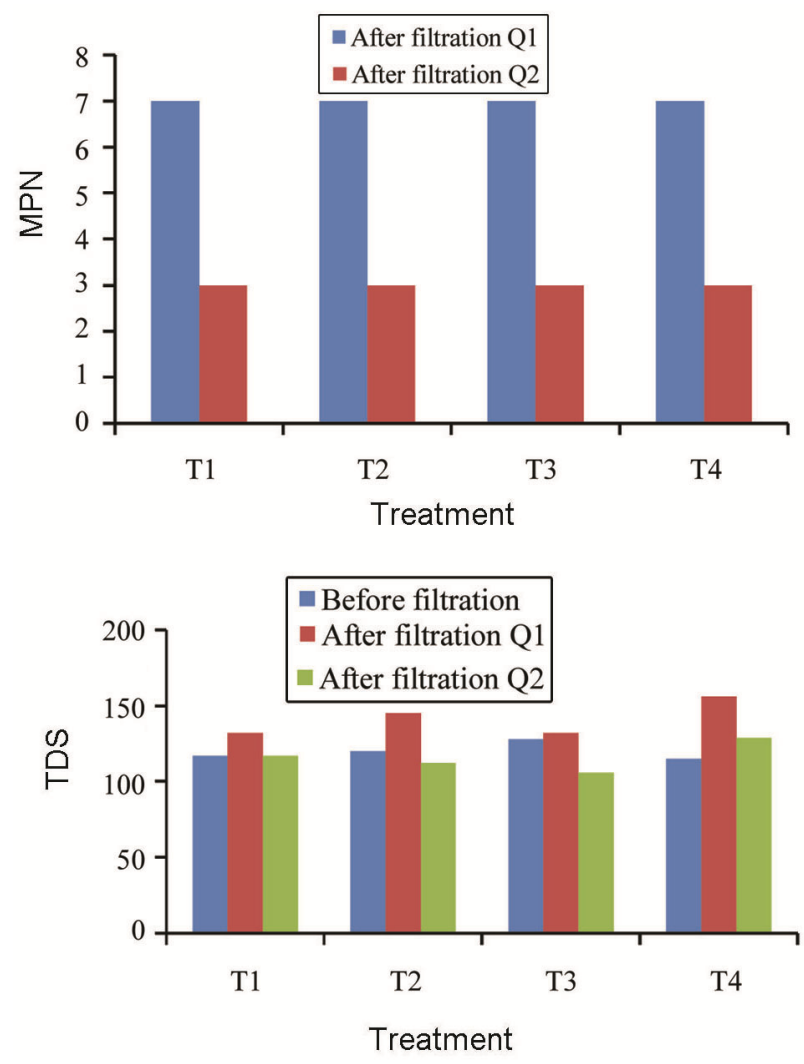

Figure 4. MPN and TDS of water at different discharge rates.

\section{Analysis of total suspended solids of canal water before and after filtration}

TSS of canal water before and after filtration was analysed for two concentrations of wash loads, viz. 1500 and $2000 \mathrm{ppm}$. The TSS values after filtration under the four treatments were found to be 760,560, 280 and $400 \mathrm{ppm}$ respectively, for wash load $1500 \mathrm{ppm}$ and 1024, 687, 384 and $551 \mathrm{ppm}$ respectively, for wash load $2000 \mathrm{ppm}$ (Table 5). The maximum percentage of suspended solids after filtration through composite radial filter was found to be 50 from treatment $T_{1}$ and minimum was 19 from
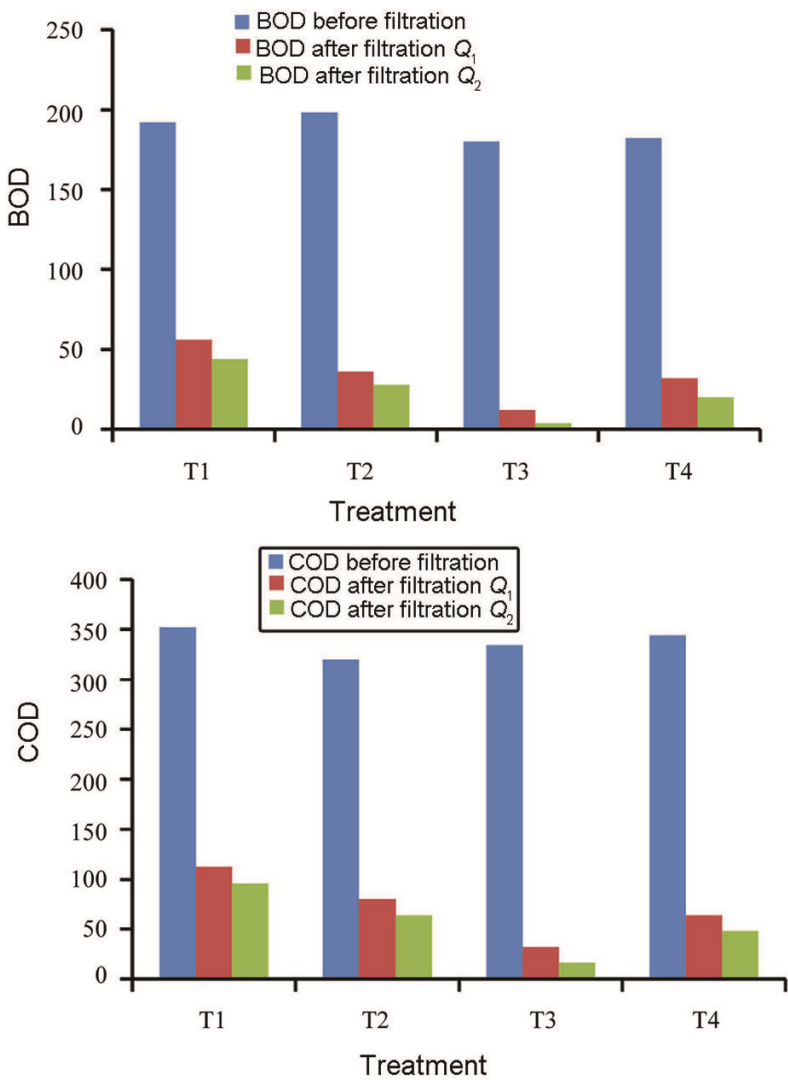

Figure 5. BOD and COD of water after and before filtration at different treatment.

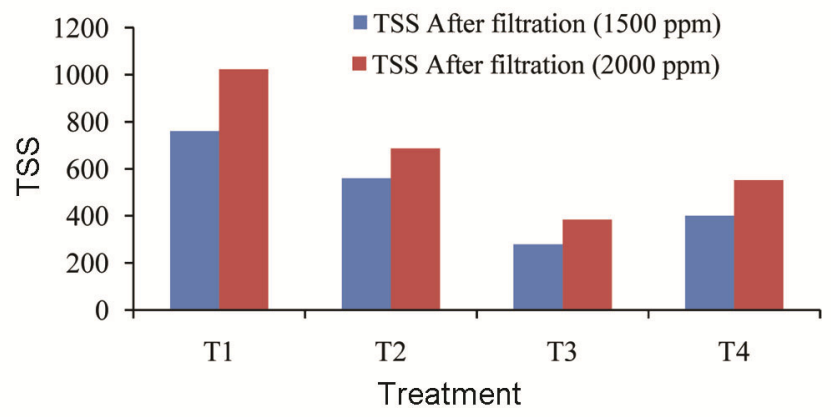

Figure 6. Total suspended solids (TSS) of filtered water from various treatments. 
treatment $T_{3}$ (Table 5 and Figure 6). The filter medium under treatment $T_{3}$ was again found to be the best for removing suspended solids from canal water.

\section{Summary and conclusion}

A laboratory-scale model of composite radial filter consisting of charcoal, coarse sand and gravel has been designed and evaluated for recharging aquifers with canal water. Sodium hypochlorite solution was injected through the chlorination unit at the outlet of the radial filter to remove bacteriological contamination of filtered water. The flow equation through composite radial filter was developed and verified through experiment. The performance of composite radial filter was evaluated by analysing water quality parameters before and after filtration with discharge rate of 0.3 and $1.3 \mathrm{lps}$ respectively, for four combination treatments of filter materials with thickness ratios of $1: 1: 1,1: 1: 2,1: 2: 2$ and $1: 2: 1$. The following conclusions emerge from this study. (i) Water-quality parameters of filtered water were found to be within permissible limits at low flow rate $(0.3 \mathrm{lps})$ except BOD and COD. (ii) The filter medium with treatment $T_{3}$ having thickness 10,20 and $20 \mathrm{~cm}$ for C, course sand and gravel filter materials respectively, was found to be the best combination for filtration of canal water. (iii) The equation for design depth of the filter for a given discharge was obtained.

1. Rodell, M., Velicogna, I. and Famiglietti, J. S., Satellite-based estimates of groundwater depletion in India. Nature, 2009. 460(7258), 999-1002.

2. Kamra, S. K. and Sharma, D. K., Groundwater recharge structures for small farmers in alluvial regions. In Third Ground Water Congress, Central Ground Water Board, Ministry of Water Resources, Government of India, 2011, 22-23, pp. 168-174.

3. Kumar, S., Kamra, S. K., Yadav, R. K. and Sharma, J. P., Evaluation of sand-based storm water filtration system for groundwater recharge wells. Curr. Sci., 2012, 103(4), 395-404.

4. Ramachandrappa, B. K., Thimmegowda, M. N., Anitha, M., Sathish, A., Devaraja. K. and Jagadeesh, B. N., Studies on borewell recharge through filter bed using runoff water in eastern dry zone of Karnataka. Indian J. Dryland Agric. Res. Dev., 2016, 30(2), 44-49.

5. Verma, O. P., Khanan, B. and Shukla, S., Determination of physico-chemical characteristics of four canals of Allahabad region and its suitability for irrigation. Adv. Appl. Sci. Res., 2012, 3, 15311537.

6. Matta, G., Pandey, R. R. and Saini, K. K., Assessment of pollution on water quality and phytoplankton diversity in canal system of river Ganga. World Res. J. Pharmaceut. Res., 2015, 4, 889908.

7. Channa, Ali S, Jakhrani, A. Q., Mukwana, K. C. and Jakhrani, S. H., Analysis of physico-chemical and biological quality parameters of Phuleli canal water and wastewater adjacent to Hyderabad city. J. Eng. Sci. Technol., 2015, 14, 26-33.

8. Zhanga, X., Zhaoa, X., Zhanga, M. and Qian-yuan, W., Safety evaluation of an artificial groundwater recharge system for reclaimed water reuse based on bioassays. Curr. Sci., 2011, 10(5), $657-661$.

9. McCormick, R. L., Filter pack installation and redevelopment techniques for shallow recharge shafts. Ground Water, 2017, 12(5), 400-405.

10. Czarnecki, J. B., Artifical recharge system. US Geol. Surv., 2012, 13(5), 891-893.

11. Anon., Annual report of AICRP - Groundwater utilization through tubewells and pumps. Artificial recharge studies. Department of Soil Water Eng. PAU, Ludhiana, 1995.

12. Kandra, H. S., Deletic, A. and McCarthy, D., Assessment of impact of filter design variables on clogging in storm water filters. Water Res. Manage., 2014, 28(1), 1873-1885.

13. Pendker, M. S., Choulwar, S. B., Rao, C. S., Chary, G. R. and Baviskar, V. S., Design, development and evaluation of artificial well recharging system for groundwater enhancement. Indian J. Dryland Agric. Res. Dev., 2014, 29(2), 17-22.

14. Kambale, J. B., Sarangi, A., Singh, D. K. and Singh, A. K., Performance evaluation of filtration unit of groundwater recharge shaft: laboratory study. Curr. Sci., 2009, 96, 471-474.

15. Krishna, K. S. and Jain, P., Performance evaluation of filtration system for groundwater recharging well in the presence of medium sand-mixed storm water. World Acad. Sci., 2015, 9(3), $224-227$.

Received 7 August 2017; revised accepted 14 February 2019

doi: $10.18520 / \mathrm{cs} / \mathrm{v} 117 / \mathrm{i} 1 / 87-93$ 